\title{
Resistance of Grapevine Rootstocks to Meloidogyne incognita under Field Conditions ${ }^{1}$
}

\author{
J.T. Loubser ${ }^{\text {a) }}$ and A.J. Meyer ${ }^{\text {b) }}$ \\ a) Viticultural and Oenological Research Institute. Private Bag X5026. 7600 Stellenbosch. Republic of South Africa. \\ b) Department of Entomology and Nematology. University of Stellenbosch, 7600 Stellenbosch. Republic of South Africa.
}

Submitted for publication: September 1987

Accepted for publication: October 1987

Keywords: Grapevine, Meloidogyne, resistance.

\begin{abstract}
Resistance of grapevine rootstocks to root-knot nematodes (Meloidogyne incognita) was studied in field trials. Resistance was found to be adequately expressed by the degree of galling. A highly significant positive correlation exists between nematode populations in the soil as well as nematode reproduction and galling, while grapevine growth and yield were negatively related to the degree of infestation. However, information regarding rootstock tolerance and intolerance (sensitivity) was not considered reliable. It was further shown that a susceptible scion would not lower the resistance of the rootstock involved. Based on their rate of galling, rootstocks Ramsey, 99 Richter PS, Dogridge, Freedom, Harmony and 101-14 Mgt are resistant while Jacquez, 140 Ruggeri, Grezot-1, Maléque 44-53 and Constantia Metallica are susceptible.
\end{abstract}

The use of grapevine rootstocks became a general practice in South Africa some 100 years ago because of the phylloxera problem. However, many Vitis vinifera L. cultivars are still being planted ungrafted in certain areas and nematode susceptible rootstocks such as Jacquez $(V$. aestivalis $\times$. cinerea $\times$. vinifera $)$ are often used.

Several reports on the susceptibility of grapevine rootstocks to the economically most important plant parasitic nematodes, viz. root-knot nematodes (Meloidogyne spp.), have been published (Lider, 1960; 1977; Raski, Hart \& Kasimatis, 1973; Raski, Schmitt \& Hemstreet, 1973; Sauer, 1977; Boubals, 1979; Furkaliev, 1979; Stirling \& Cirami, 1984; Cirami \& Nicholas. 1985). Different pathotypes of the various Meloidogyne species exist (Sasser, 1966; Southards \& Priest, 1973; Dalmasso \& Cuani, 1976; Stoyanov, 1979; Cain, McKenry \& Tarailo, 1984) and this may cause rootstocks to be infected to a different degree under South African conditions. For this reason, and because root-knot nematodes occur commonly in South African vineyards (Smith, 1977), the evaluation of rootstocks under local conditions in more than one area is essential.

Resistance and susceptibility of host plants are defined in various ways (Seinhorst, 1967), making it difficult to compare results recorded by different workers. A need therefore exists to determine and define resistance of as many grapevine rootstocks as possible against root-knot nematodes under similar conditions. On grapevines, resistance to root-knot nematodes is usually assessed by the degree of galling (Snyder, 1936; Boubals, 1954; Taylor, 1971 acc. to Fassuliotis, 1979; Stirling \& Cirami, 1984). This should be an ideal criterion for resistance or susceptibility since galling implies successful parasitism. It takes into account all stages of parasitism such as penetration, infection, development and reproduction which may differ from one host to another (Ferris \& Hunt, 1979; Ferris, Schneider \& Stuth, 1982).

Host reaction to infestation and galling, however, is an aspect which is very often neglected. Certain hosts may harbour high numbers of root-knot nematodes without showing any decline in growth or yield. Other hosts may be very sensitive (intolerant) to nematode infestation, with low populations having a very serious effect on growth. Such tolerant and intolerant cultivars (Dropkin \& Nelson, 1960; Rohde, 1972) would only become evident after some considerable time and may be identified by high infestation/high yield (growth) and low infestation/low yield respectively. There is a need to determine this type of relationship for all grapevine rootstock cultivars available and this was one of the objectives of the present study.

Resistance breakdown or increase in susceptibility, due to grafting, is a further aspect of grapevine/nematode interaction which has not received any attention in the past. According to Marais (1983), the resistance of certain grapevine rootstocks to Phytophthora cinnamo$m i$ increased when grafted with a $P$. cinnamomi resistant scion. Forster (1956) found that a resistant tomato scion made the roots less susceptible to $M$. incognita. It was therefore important to investigate whether a similar nematode/grapevine/graft reaction occurs.

\section{MATERIALS AND METHODS}

Relationship between galling and nematode reproduction, grapevine growth and yield

Evaluations regarding the intensity of galling, the number of nematodes present in the soil and their reproduction, as well as the growth and yield of infested vines were made. This was done in an eight-year-old vineyard at Vaalharts established on a loamy sand with a high infestation of Meloidogyne incognita. The vineyard consisted of six rootstocks grafted with Clairette blanche (Vitis vinifera L.) and the ungrafted scion. Each rootstock and scion treatment consisted of 25 vines and was replicated four times in a randomised block design.

Soil and root samples were collected during autumn

\footnotetext{
${ }^{1}$ Part of a thesis to be submitted by the senior author to the University of Stellenbosch for the Ph.D. (Agric.) degree.
} 
from each rootstock/scion plot. Soil samples consisted of a composite of 25 cores which were collected at 100 $450 \mathrm{~mm}$ depth within $300 \mathrm{~mm}$ from 25 separate vines. Nematodes were extracted by a sieving sedimention method (Loubser, 1985).

Root samples were collected at $100-450 \mathrm{~mm}$ depth from five randomly chosen vines per rootstock. Galling was assessed visually and rated on a 0-5 scale as done by Boubals (1954), but with the following percentages for each infestation class:

0 : no galls

1 : between $1-20 \%$ of roots galled

2 : between $21-40 \%$ of roots galled

3 : between $41-60 \%$ of roots galled

4 : between $61-80 \%$ of roots galled

5 : between $81-100 \%$ of roots galled

A composite $30 \mathrm{~g}$ root aliquot was used for nematode egg extraction by the method of Hussey \& Barker (1973).

Growth and yield of the vines were assessed on the average cane and bunch mass per vine measured over a three year period. Correlations between galling and nematode reproduction, as well as between soil populations, were determined using Spearman's correlation coefficient by ranks (Siegel, 1956).

\section{Rootstock resistance to $M$. incognita at Upington}

Thirty eight rootstock cultivars and crosses were planted during August in a loamy sand ( $8 \%$ clay). Soil samples taken from the site in autumn before planting showed that Meloidogyne incognita larvae were present at an average of 1960 larvae per $250 \mathrm{cc}$ soil. Vines consisted of one-year-old ungrafted cuttings previously rooted in sterilised peat moss/sand $(1: 2)$ in a glasshouse. Each treatment consisted of six vines per rootstock randomly planted in five replicates. Spacing was one metre between vines planted in rows three metres apart. After 13 months root samples were collected from the two centre vines in each treatment plot and the degree of galling was assessed as described above. Only the maximum galling on either of the two vines was recorded.

\section{Rootstock resistance to $M$. incognita at Vaalharts}

Rootstock cultivars and crosses were planted during August in a loamy sand (6\% clay, pH (KCL) 5.7) kriown to be infested by $M$. incognita (an average of 2480 larvae per $250 \mathrm{cc}$ soil extracted during autumn). One-year-old rooted, ungrafted cuttings were used and planted randomly, $0,5 \mathrm{~m}$ apart, in rows two metres apart. Each treatment consisted of six vines per rootstock and was replicated five times. This experiment was duplicated in an adjacent block fumigated with ethylene dibromide (EDB fum-soln; $200 \mathrm{l} / \mathrm{ha}$ ). Plants in the fumigated plot served as controls to determine the effect of nematodes on growth.

Twelve and 24 months after planting both root galling and plant growth were recorded. During each evaluation three vines per replicate of each treatment were removed and the roots washed free of soil. During the first evaluation fresh root mass and shoot mass were measured while galling was assessed as described above. Galling of the vine showing highest infestation in each plot was recorded. During the second evaluation, plant growth was measured as fresh shoot mass only while galling was rated as before. Growth was measured in the same way in the fumigated block and the percentage difference in root and shoot mass between rootstocks planted on infested and fumigated soil was calculated.

The overall correlation between the average galling and shoot mass decrease over the two years, as well as root mass decrease, was calculated using Spearman's correlation by ranks (Siegel, 1956).

\section{Effect of grafting on rootstock susceptibility to $M$. in- cognita}

Ten rootstock cultivars were planted as ungrafted as well as grafted rooted cuttings. Chenin blanc, a rootknot nematode susceptible cultivar of Vitis vinifera, was used as scion material. Each treatment consisted of six vines and was replicated five times for both grafted and ungrafted grapevines per rootstock in a soil containing high $M$. incognita populations. Three vines of each treatment were removed five and twelve months after planting and the highest degree of galling was recorded.

\section{RESULTS AND DISCUSSION}

\section{Relationship between galling and nematode reproduc-} tion, grapevine growth and yield

Galling correlated with both reproduction (number of eggs) $\left(r_{s}=0,9643\right)$ and number of larvae in the soil $\left(r^{s}=0,9286\right)$ (Table 1). Visible galls are therefore a good indication of nematode reproduction and can be regarded as an indication of resistance of grapevine rootstocks to root-knot nematodes. Root-knot nematode infestations without the formation of galls have, however, been shown to exist (Fox \& Miller, 1973; Golden, Rose \& Bird, 1980), and therefore galling may not always be a reliable criterion of rootstock susceptibility.

\section{TABLE 1}

Relationship between galling, nematode (Meloidogyne incognita) reproduction and grapevine growth and yield (Vaalharts).

\begin{tabular}{|l|c|r|r|r|r|}
\hline \multicolumn{1}{|c|}{ Rootstock } & Galling & $\begin{array}{r}\text { Repro- } \\
\text { duction }\end{array}$ & Larvae & Growth & Yield \\
\hline Ramsey & 0 & 26.0 & 27.5 & 1.20 & 17.0 \\
99 Richter & 0.5 & 76.0 & 22.5 & 0.98 & 12.3 \\
101-14 Mgt & 1.0 & 123.3 & 42.5 & 0.72 & 9.5 \\
110 Richter & 3.0 & 231.0 & 70.0 & 0.75 & 10.5 \\
Jacquez & 4.0 & 309.5 & 130.0 & 0.65 & 6.8 \\
C. Metallica & 4.5 & 1242.8 & 267.5 & 0.85 & 7.3 \\
Clairette blanche & 5.0 & 337.0 & 175.0 & 0.41 & 3.0 \\
\hline
\end{tabular}

1 Expressed as the average of four replicates according to a degree of galling rated from 0 to 5

2 Number of eggs $\left(x 10^{2}\right)$ per 30 g root samples

3 Number of second stage larvae (x 10) per $250 \mathrm{cc}$ soil

4 Assessed on cane mass $(\mathrm{kg})$ pruned per vine (average of 25 vines over a three year period)

5 Yield ( $\mathrm{kg}$ ) per vine (average of 25 vines over a three year period)

Table 1 also shows the concordance between growth, yield and nematode infestation. The slightly better growth and higher yields achieved with 110 Richter compared to 101-14 Mgt in spite of its higher degree of infestation, may imply that this rootstock has a certain degree of tolerance to root-knot nematodes. This may 
also be the case with $\mathrm{C}$. Metallica, a rootstock generally believed to be resistant because of its good performance in the field. It must be emphasized that the influence which the genetic effect of the rootstocks might have had on growth and yield, was not taken into account during the calculations in this experiment.

\section{Rootstock resistance to $M$. incognita at Upington}

Results of grapevine rootstock resistance to Meloidogyne incognita as evaluated at Upington, are listed in Table 2. Rootstocks were classified according to the de-

\section{TABLE 2}

Resistance of grapevine rootstocks to Meloidogyne incognita according to a field trial at Upington.

\begin{tabular}{|c|c|c|}
\hline $\begin{array}{c}\text { Resistance } \\
\text { classifications }^{1}\end{array}$ & Rootstock & Galling \\
\hline \multirow[t]{12}{*}{ Resistant } & 99 Richter P.S. & 0,0 \\
\hline & Ramsey & 0,2 \\
\hline & Harmony & 0,2 \\
\hline & US $4-4$ & 0,4 \\
\hline & Selection Oppenheim no. 4 & 0,4 \\
\hline & $26 \mathrm{G}$ & 0,6 \\
\hline & Kober 5 BB & 0,6 \\
\hline & Freedom & 0,6 \\
\hline & 1045 Paulsen & 0,8 \\
\hline & 99 Richter & 1,0 \\
\hline & US 24-10 & 1,0 \\
\hline & 775 Paulsen & 1,0 \\
\hline \multirow{14}{*}{$\begin{array}{l}\text { Moderately } \\
\text { resistant }\end{array}$} & & \\
\hline & $101-14 \mathrm{Mgt}$ & 1,2 \\
\hline & US $16-13-23$ & 1,2 \\
\hline & Kober $125 \mathrm{~A}$ & 1,2 \\
\hline & US 3-6 & 1,6 \\
\hline & Berlandieri 35-1-15 & 1,6 \\
\hline & 110 Richter & 1,8 \\
\hline & US 2-1 & 1,8 \\
\hline & US 24-26 & 2,0 \\
\hline & Païs & 2,0 \\
\hline & $143 \mathrm{~B} \mathrm{Mgt}$ & 2,0 \\
\hline & 1103 Paulsen & 2,0 \\
\hline & $4401 \mathrm{C}$ & 2,0 \\
\hline & Teleki $5 \mathrm{C}$ & 2,0 \\
\hline \multirow{9}{*}{$\begin{array}{l}\text { Moderately } \\
\text { susceptible }\end{array}$} & & \\
\hline & $161 / 49 \mathrm{C}$ & 2,6 \\
\hline & US 1-6 & 2,8 \\
\hline & 140 Ruggeri & 3,4 \\
\hline & $216 / 3 \mathrm{C}$ & 3,2 \\
\hline & $3309 \mathrm{C}$ & 3,0 \\
\hline & US 12-6-8 & 3,0 \\
\hline & C. Metallica & 3,6 \\
\hline & Jacquez & 3,6 \\
\hline \multirow[t]{5}{*}{ Susceptible } & 333 EM & 4,0 \\
\hline & A $\times$ RG II & 4,0 \\
\hline & $1202 \mathrm{C}$ & 4,4 \\
\hline & Grezot-1 & 5,0 \\
\hline & 44-53 Maléque & 5,0 \\
\hline
\end{tabular}

1 Resistance classification is an arbitrary division based on the average degree of galling.

2 Galling is expressed according to an index from 0 to 5 . The average of five replicates is listed. gree of galling as resistant $(0-1,0)$, moderately resistant $(1,1-2,5)$, moderately susceptible $(2,6-3,9)$ and susceptible $(4,0-5,0)$.

The resistance grouping achieved in this way, shows agreement with that of other workers. Results for Ramsey, Harmony and Freedom, designated as resistant, are similar to those obtained by Snyder (1936), Lider (1960) and Stirling \& Cirami (1984). Furthermore, rootstocks 333 EM, A x RG II and 1202 C were also considered susceptible by Boubals (1979) and Furkaliev (1979). On the other hand, Kober 5BB and 140 Ruggeri were found to be moderately resistant by Stirling \& Cirami (1984), but were resistant and moderately susceptible respectively in the present study. Boubals (1979) designated 1103 Paulsen as resistant and 110 Richter as susceptible, while we found both these cultivars to be moderately resistant. These differences in degrees of resistance may be attributed to differences in field conditions, clonal differences in rootstocks or a variation in virulence between the Meloidogyne species involved.

\section{Rootstock resistance to $M$. incognita at Vaalharts}

Resistance of the rootstocks planted in infested soil and differences in shoot and root mass between infested plants and plants from the fumigated block, are shown in Table 3. Resistance classification was done in the same way as for the Upington trial by grouping rootstocks according to their average degree of galling for both years.

Galling as well as the decrease in shoot mass varied from year to year. The variation in galling was, however, very little and although resistance grouping of certain rootstocks would have changed if based on one year's rating only, no rootstock changed from resistant to susceptible in consecutive years.

Shoot mass decrease of rootstocks varied widely from year to year. In most cases the percentage decrease was less in the second year. This could mean a recovery from the initial set-back caused by nematode infestation. It might also be an indication of tolerance. Although it was impossible to make accurate root mass measurements during the second year, it is assumed that it would have followed the same pattern as shoot mass.

A significant $(P \leqslant 0,01)$ overall correlation was demonstrated between average galling and decrease in shoot mass $\left(r_{s}=0,6673\right)$ as well as root mass $\left(r_{s}=0,6374\right)$. This implies that plant growth response is a good indicator of resistance or susceptibility. This correlation does not apply to all rootstocks when considered individually. Rootstocks which deviate from others within the same group in terms of shoot and root mass, may additionally be classified as tolerant or intolerant (sensitive). Tolerance or intolerance measured under field conditions at such an early stage is very variable and may therefore not be a reliable indication of tolerance or intolerance in more mature vines.

Resistance classifications at Vaalharts were very similar to those of Upington. On the other hand, while most rootstocks showed a higher degree of galling at Vaalharts, certain rootstocks also showed a marked difference in galling compared to the Upington trial; viz. US $16-13-23$ (3,6 against 1,2$)$; US $3-6$ (3,5 against 1,6$)$; US 4-4 (2,1 against 0,4$)$ and 110 Richter $(3,2$ against 
TABLE 3

Resistance of grapevine rootstocks to Meloidogyne incognita according to a field trial at Vaalharts.

\begin{tabular}{|c|c|c|c|c|c|c|c|c|c|}
\hline Rootstock & Cross or species & 1st year & $\begin{array}{l}\text { Galling } \\
\text { 2nd year }\end{array}$ & Average & $\begin{array}{l}\text { Shoot } \\
\text { 1st yea }\end{array}$ & $\begin{array}{l}\text { aass de } \\
\text { 2nd y }\end{array}$ & $\begin{array}{l}\mathrm{se}^{2}(\%) \\
\text { Average }\end{array}$ & $\begin{array}{c}\text { Root mass } \\
\text { decrease }^{2}(\%) \\
\text { lst year }\end{array}$ & $\begin{array}{c}\text { Resistance } \\
\text { classification }\end{array}$ \\
\hline $\begin{array}{l}\text { Ramsey } \\
\text { Dogridge } \\
99 \text { Richter P.S. } \\
775 \text { Paulsen } \\
\text { Freedom } \\
\text { Selection } \\
\text { Oppenheim } 4 \\
\text { 101-14 Mgt } \\
\text { US 24-10 } \\
\text { Berlandieri }\end{array}$ & $\begin{array}{l}\text { V. champini } \\
\text { V. champini } \\
\text { V. berlandieri x V. rupestris } \\
\text { V. berlandieri x V. rupestris } \\
1613 \text { x Dogridge } \\
\text { V. berlandieri x V. riparia } \\
\text { V. riparia x V. rupestris } \\
\text { Ramsey x } 99 \text { Richter } \\
\text { Selection V. berlandieri }\end{array}$ & $\begin{array}{l}0 \\
0 \\
0 \\
1,0 \\
0,5 \\
1,0 \\
1,4 \\
0,6 \\
1,4\end{array}$ & $\begin{array}{l}0 \\
0 \\
0 \\
0,4 \\
1,0 \\
0,8 \\
0,4 \\
1,2 \\
0,6\end{array}$ & $\begin{array}{l}0 \\
0 \\
0 \\
0,7 \\
0.7 \\
0.9 \\
0.9 \\
0.9 \\
1.0\end{array}$ & $\begin{array}{l}36 \\
3 \\
16 \\
44 \\
52 \\
\\
19 \\
25 \\
13 \\
13\end{array}$ & $\begin{array}{l}6 \\
0 \\
5 \\
6 \\
49\end{array}$ & $\begin{array}{l}21 \\
2 \\
11 \\
25 \\
51 \\
\\
20 \\
28 \\
19 \\
7\end{array}$ & $\begin{array}{l}46 \\
35 \\
13 \\
47 \\
0 \\
\\
37 \\
42 \\
2 \\
24\end{array}$ & Resistant \\
\hline $\begin{array}{l}1103 \text { Paulsen } \\
\text { US 2-3 } \\
\text { Teleki 5B } \\
\text { 1045 Paulsen } \\
\text { Kober 5BB } \\
\text { Kober 125AA } \\
\text { US 1-4 } \\
\text { US 2-1 } \\
\text { US 4-4 } \\
\text { 143 B Mgt } \\
\text { US 4-7 } \\
\text { US 6-2 } \\
\text { 3306 C } \\
99 \text { Richter } \\
\text { Solonis } \\
\text { US 1-9 }\end{array}$ & 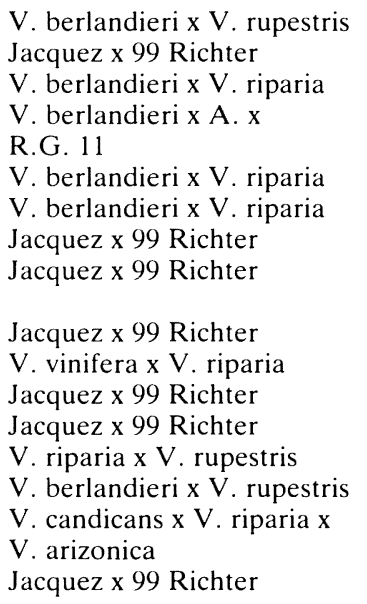 & $\begin{array}{l}1,4 \\
1,2 \\
1,2 \\
1,6 \\
1,6 \\
1,8 \\
2,2 \\
2,4 \\
1,8 \\
2,4 \\
2,2 \\
2,2 \\
2,4 \\
2,2 \\
2,2 \\
2,4\end{array}$ & $\begin{array}{l}0,8 \\
1,2 \\
1,2 \\
0,8 \\
1,6 \\
1,8 \\
1,6 \\
1,4\end{array}$ & $\begin{array}{l}1,1 \\
1.2 \\
1,2 \\
1,2 \\
1,6 \\
1.8 \\
1,9 \\
1,9\end{array}$ & $\begin{array}{l}15 \\
77 \\
64 \\
61 \\
39 \\
43 \\
78 \\
16 \\
\\
0 \\
5 \\
66 \\
79 \\
81 \\
68 \\
62 \\
81\end{array}$ & $\begin{array}{l}0 \\
52 \\
38 \\
0 \\
0 \\
41 \\
0 \\
36\end{array}$ & $\begin{array}{l}8 \\
65 \\
51 \\
31 \\
20 \\
42 \\
39 \\
26 \\
\\
0 \\
13 \\
33 \\
67 \\
55 \\
51 \\
55 \\
73\end{array}$ & $\begin{array}{l}23 \\
72 \\
66 \\
41 \\
46 \\
57 \\
74 \\
28 \\
\\
0 \\
37 \\
63 \\
63 \\
65 \\
51 \\
51 \\
79\end{array}$ & $\begin{array}{l}\text { Moderately re- } \\
\text { sistant }\end{array}$ \\
\hline $\begin{array}{l}\text { 1447 Paulsen } \\
\text { 110 Richter } \\
\text { Païs } \\
\text { Vivet } 15 \\
\text { US 3-6 } \\
\text { US 16-13-23 } \\
\\
\text { US 12-6-8 } \\
161 / 49 \text { C } \\
\text { US 1-6 } \\
\text { US 16-13-26 } \\
\text { US 8-7 }\end{array}$ & $\begin{array}{l}\text { V. berlandieri } \times \text { V. rupestris } \\
\text { V. berlandieri x V. rupestris } \\
\text { V. rupestris } \times \text { V. berlandieri } \\
\text { Jacquez } \times 99 \text { Richter } \\
1202 \text { C x } 99 \text { Richter } \\
\\
\text { Jacquez } \times 99 \text { Richter } \\
\text { V. berlandieri } \times \text { V. riparia } \\
\text { Jacquez } \times 99 \text { Richter } \\
1202 \text { C } 99 \text { Richter } \\
\text { Jacquez } \times 99 \text { Richter }\end{array}$ & $\begin{array}{l}3,0 \\
3,2 \\
3,4 \\
3,2 \\
3,6 \\
3,4 \\
\\
4,0 \\
3,8 \\
4,0 \\
3,8 \\
4.0\end{array}$ & $\begin{array}{l}2,4 \\
3,2 \\
3,2 \\
3,6 \\
3,4 \\
3,8 \\
\\
3,2 \\
3,8 \\
3,6 \\
4,0 \\
3,8\end{array}$ & $\begin{array}{l}2.7 \\
3.2 \\
3.3 \\
3.4 \\
3.5 \\
3.6 \\
\\
3.6 \\
3.8 \\
3.8 \\
3.9 \\
3.9\end{array}$ & $\begin{array}{l}59 \\
42 \\
46 \\
36 \\
9 \\
38 \\
\\
87 \\
80 \\
34 \\
69 \\
63\end{array}$ & $\begin{array}{l}12 \\
73 \\
0 \\
68 \\
58 \\
24\end{array}$ & $\begin{array}{l}36 \\
58 \\
23 \\
52 \\
34 \\
31 \\
\\
83 \\
76 \\
32 \\
37 \\
64\end{array}$ & $\begin{array}{l}60 \\
34 \\
61 \\
24 \\
0 \\
47 \\
\\
89 \\
69 \\
37 \\
67 \\
67\end{array}$ & $\begin{array}{l}\text { Moderately } \\
\text { susceptible }\end{array}$ \\
\hline $\begin{array}{l}\text { Jacquez } \\
\text { US 3-5 } \\
\text { 196/17C } \\
\text { C. Metallica } \\
\text { 140 Ruggeri } \\
\text { Grezot-1 } \\
\text { 216/3 C } \\
\text { Maléque 44-53 }\end{array}$ & $\begin{array}{l}\text { V. aestivalis } \times \text { V. cinerea } \\
\times \text { V.vinifera } \\
\text { Jacquez } \times 99 \text { Richter } \\
1201 \mathrm{C} \times \mathrm{V} \text {. riparia } \\
\text { V. rupestris var. Martin } \\
\text { V. berlandieri } x \text { V. rupestris } \\
1616 \times \mathrm{V} \text {. rupestris } \\
\text { Solonis } \times \mathrm{V} \text {. rupestris } \\
\text { V. riparia } \times(\mathrm{V} \text {. cordifolia } \\
\times \text { V. rupestris) }\end{array}$ & $\begin{array}{l}4,0 \\
4,0 \\
4,4 \\
4,0 \\
4,2 \\
4,8 \\
4,8 \\
\\
4,8\end{array}$ & $\begin{array}{l}4,0 \\
4,0 \\
4,2 \\
4,6 \\
4,8 \\
5,0 \\
5,0 \\
\\
5,0\end{array}$ & $\begin{array}{l}4.0 \\
4,0 \\
4.3 \\
4.3 \\
4.5 \\
4.9 \\
4,9\end{array}$ & $\begin{array}{l}80 \\
66 \\
68 \\
48 \\
85 \\
61 \\
82 \\
78\end{array}$ & $\begin{array}{l}60 \\
42 \\
40 \\
24 \\
66 \\
76 \\
79\end{array}$ & $\begin{array}{l}70 \\
54 \\
54 \\
36 \\
76 \\
69 \\
81 \\
78\end{array}$ & $\begin{array}{l}64 \\
46 \\
32 \\
61 \\
69 \\
68 \\
64 \\
63\end{array}$ & Susceptible \\
\hline
\end{tabular}

1 Galling is expressed according to an index from 0-5. The average of five replicates is listed.

2 Shoot and root mass decrease are the averages of five replicates and were calculated as a decrease in mass between infested and control plants.

3 Resistance classification is an arbitrary division based on the average degree of galling for the two years.

1,8). Four rootstocks, viz. US 3-6; US 16-13-23; 110 Richter and Païs, changed from moderately resistant to moderately susceptible. These differences are difficult to explain and could be ascribed to root-knot nematode race or biotype preferences as shown by Sasser (1966), Dalmasso \& Cuany (1976) and Southards \& Priest (1973). Environmental effects are also possible (Wallace, 1983) and warrant further investigation.
Effect of grafting on rootstock susceptibility to $M$. incognita

Table 4 indicates that the susceptible $V$. vinifera scion, Chenin blanc, did not decrease the resistance of the rootstocks involved.

\section{CONCLUSIONS}

Evaluating grapevine rootstocks in short term field 


\section{TABLE 4}

Resistance of grafted and ungrafted grapevine rootstocks to root-knot nematodes (Meloidogyne incognita).

\begin{tabular}{|l|r|c|}
\hline \multirow{2}{*}{ Rootstock } & \multicolumn{2}{|c|}{ Galling' } \\
\cline { 2 - 3 } & Grafted & Ungrafted \\
\hline Ramsey & 0 & 0 \\
99 Richter & 0,1 & 0,1 \\
143 B Mgt & 0 & 0 \\
101-14 Mgt & 0 & 0 \\
110 Richter & 0,3 & 0,4 \\
1045 Paulsen & 0 & 0,2 \\
US 2-1 & 2,0 & 3,3 \\
C. Metallica & 3,4 & 4,6 \\
US 3-6 & 2,8 & 3,2 \\
Jacquez & 2,2 & 3,0 \\
\hline
\end{tabular}

1 Expressed as the average of five replicates according to a degree of galling rated from 0 to 5 at five and twelve months after planting

trials for resistance to Meloidogyne incognita is easy to perform and reliable results can be obtained. Galling of grapevine roots corresponds well with nematode reproduction and soil populations, making it a reliable indication of root-knot nematode resistance of this host.

Field trials in different regions gave similar results for rootstock resistance. The few differences found suggest that differences which warrant futher investigation occur among Meloidogyne incognita populations. Tolerant and intolerant cultivars could not be reliably identified by these short term field experiments. It is assumed that the growth response of grapevines to nematode infestation will only become evident after several years. It was further shown that the susceptible scion, Chenin blanc, did not lower the resistance of any of the rootstocks tested. The present findings support those of other workers to a large extent and suggest a wide horizontal resistance in grapevines to Meloidogyne species.

Rootstocks which are designated resistant should be used when planting on sandy, infested soils and when replanting on old vineyard soil. Most moderately resistant rootstocks would also perform satisfactorily under low infestations and optimal soil conditions. Rootstocks designated moderately susceptible or susceptible should only be considered when establishing on heavier soils.

\section{LITERATURE CITED}

BOUBALS, D., 1954. Les nématodes parasites de la vigne. Progrès agric. vitic. 141, 173-182 and 204-208.

BOUBALS. D., 1979. Situation des porte-greffes résistants aux nematodes ravageurs directs. Bull. De L'O.I.V. 52-578, 263-271.

CAIN. D.W.. McKENRY, M.V. \& TARAILO, R.E., 1984. A new pathotype of root-knot nematode on grape rootstocks. J. Nematol. 16, 207-208.
CIRAMI, R. \& NICHOLAS, P., 1985. Field trials evaluated performance of rootstocks in nematode-infested soils. Aust. Grapegrower and Winemaker 262, 12.

DALMASSO, A. \& CUANI. A.. 1976. Résistance des porte-greffes de vignes à differentes populations du nematode Meloidogyne hapla. Progrès agric. vitic. 93, 800-807.

DROPKIN. V.H. \& NELSON, P.E.. 1960. The histopathology of root-knot nematode infections in soybeans. Phytopathology 50, $442-447$.

FASSULIOTIS, F.. 1979. Plant breeding for root-knot nematode resistance. In: Lamberti. F. and Taylor C.E. (eds.) Root-knot nematodes (Meloidogyne species). Systematics, biology and control. Acad. Press, London, New York, pp. 425-453.

FERRIS. H. \& HUNT. W.A.. 1979. Quantitative aspects of the development of Meloidogyne arenaria larvae in grapevine varieties and rootstocks. J. Nematol. 11, 168-174.

FERRIS, H., SCHNEIDER. S.M. \& STUTH, M.C.. 1982. Probability of penetration and infection by root-knot nematode. Meloidogyne arenaria, in grape cultivars. Am. J. Enol. Vitic. 33, 31-35.

FORSTER, A.R., 1956. Development of Heterodera rostochiensis and Meloidogyne incognita in cross-grafted solanaceous plants with different susceptibilities. Nematologica 1, 283-289.

FOX, J.A. \& MILLER, L.I., 1973. Comparison of gall and egg-mass indices of two races of Meloidogyne incognita on differential hosts. Phytopathology 63, 801 .

FURKALIEV, D.G., 1979. European experience with grape-vine rootstocks. Aust. Grapegrower and Winemaker 187, 16-17.

GOLDEN, A.M., ROSE, L.M. \& BIRD. G.W.. 1980. Description of Meloidogyne nataliei $\mathrm{n}$. sp. (Nematoda: Meloidogynidae) from grape (Vitis labrusca) in Michigan, with SEM observations. J. Nematol. 13, 393-400.

HUSSEY, R.S. \& BARKER, K.R., 1973. A comparison of methods of collecting inocula of Meloidogyne spp.. including a new technique. Pl. Dis. Rep. 57, 1025-1028.

LIDER, L.A., 1960. Vineyard trials in California with nematode-resistant grape rootstocks. Hilgardia 30, 123-152.

LOUBSER, J.T., 1985. A modified sieving-sedimentation method for extracting nematodes from soil. Hort. Sci. 3, 23-25.

MARAIS, P.G.. 1983. Phytophthora cinnamomi root rot of grapevines in South Africa. Ph.D dissertation, University of Stellenbosch, 7600 Stellenbosch, Republic of South Africa.

RASKI, D.J.. HART, W.H. \& KASIMATIS, A.N.. 1973. Nematodes and their control in vineyards. Calif. agric. Exp. Stn. circ. 533.

RASKI, D.J., SCHMITT, R.V. \& HEMSTREET, C.. 1973. Comparison of grape rootstocks in nematode infested soil after preplant soil fumigation. Pl. Dis. Rep. 57, 416-419.

ROHDE, R.A., 1972. Expression of resistance in plants to nematodes. Ann. Rev. Phytopath. 10, 233-252.

SASSER, J.N., 1966. Behaviour of Meloidogyne spp. from various geographical locations on ten host differentials. Nematologica 12, 98-99.

SAUER, M.R., 1977. Nematode resistant grape rootstocks. Dried Fruit 9, 25-29.

SEINHORST, J.W., 1967. The relationship between population increase and population density in plant parasitic nematodes. III. Definition of the terms host, host status and resistance. IV. The influence of external conditions on the regulation of population density. Nematologica 13, 429-442.

SIEGEL. S., 1956. Non-parametric statistics for the behavioral sciences. McGraw-Hill Book Co. Inc.. New York.

SMITH, P.C.. 1977. Distribution of plant-parasitic nematodes in vineyards in the Western Cape Province. Phytophylactica 9, 2728.

SNYDER, E., 1936. Susceptibility of grape rootstocks to root-knot nematodes. U.S. Dept. Agric. Circ. 405, 1-16.

SOUTHARDS, C.J. \& PRIEST, M.F., 1973. Variation in pathogenicity of seventeen isolates of M. incognita. J. Nematol. 5, 63-67.

STIRLING, G.R. \& CIRAMI, R.M., 1984. Resistance and tolerance of grape rootstocks to South Australian populations of rootknot nematodes. Aust. J. Exp. Agric. Anim. Husb. 24, 277-282.

STOYANOV, D., 1979. Pathogenicity variations of three species of root-knot nematodes. In: Lamberti, F. and Taylor. C.E. (eds.) Root-knot nematodes (Meloidogyne species). Systematics, biology and control. Acad. Press, London, New York, pp. 307-310.

WALLACE, H.R., 1983. Interactions between nematodes and other factors on plants. J. Nematol. 15, 221-227. 